\title{
Emerging Subspecialties in Neurology: Medical education
}

Patrick M. Chen, MD, and Sean J. Evans, MD

Neurology ${ }^{\circledR}$ 2019;93:273-276. doi:10.1212/WNL.0000000000007904
Correspondence

Dr. Chen

pmc003@ucsd.edu

\begin{abstract}
Medical education is the understanding of how medical knowledge is taught and practiced and encompasses not just medical students, but resident trainees, colleagues, and the community. While there is a growing emphasis in medicine on "clinician-educators," neurology training has only slowly developed formal opportunities in medical education. Here we highlight the current opportunities in residency and beyond, and explore options for further medical education infrastructure within neurology.
\end{abstract}

\section{The need for medical educators in neurology}

While an aging population and expanded therapeutics are driving demand for neurologists, neurology is ill-equipped to meet this growing need. One reason is neurophobia, a "fear of the neural sciences and clinical neurology ... due to inability to apply their knowledge of basic sciences to a clinical situation". ${ }^{1}$ Neurophobia is well-documented in students and generalist practitioners globally. ${ }^{1}$ A lack of formal education, general misunderstandings, and lack of strong neurologic role models are proposed explanations. ${ }^{1}$ A recent article by Lin et al. ${ }^{2}$ in Neurology ${ }^{\circledR}$ highlights challenges clinician educators face and notes the need for good educators in a progressively complex field to protect and incentivize the "art of neurology."

Formalized medical education can combat neurophobia and internal burnout. We note that the term "burnout" is frequently used in the press though it is still an unestablished entity under investigation. We propose a "ground up approach": develop medical educators who are role models and leaders, then update and enrich curriculums, inspire trainees, and empower them to engage meaningfully with neurology. Better trained students will help deter burnout in our residents and help remove neurology from its position in the top 5 specialties for regret and burnout. $^{3}$

While education of future neurologists is a core element of our profession, training educators has been a passive process with little formal curricula. This needs to change.

\section{The role of residents in medical education}

The resident is at the frontline of clinical teaching for medical students, serving as both near-peer and role model. One third of a medical student's fund of knowledge is acquired from resident teaching. ${ }^{4}$ The magnitude and importance of education is often at odds with the limited formal educational training provided to the neurology resident. The formal development of medical teaching skills is not an explicit requirement of programs in the Accreditation Council for Graduate Medical Education (ACGME) requirements. Although residents may spend up to one-fourth of their time supervising or teaching students and coresidents, ${ }^{4}$ the ACGME neurology milestone project places education vaguely and more broadly under "scholarly activity." The onus for structure therefore lies on the program and resident. Many programs center the role of education on the senior resident, assuming that seniority is equal to apt teaching ability, which may be 
a fallacy. In addition to conveying knowledge, residents perform educational administrative responsibilities: observation, formative assessments, and summative evaluations. A resident, juggling many tasks, may easily provide teaching suffering both in quantity and quality.

Residency program directors need to adapt their curricula to prepare all neurology residents for their role as educators, and need to demonstrate how teaching students reinforces residents' core knowledge, potentially producing happier, more successful residents who become happier, more successful neurologists.

\section{Training opportunities in neurology residency}

All neurologists need to effectively educate their patients, their colleagues, and their own trainees. In current practice, residents often self-direct their learning of medical education. Residents should familiarize themselves with basic educational theories and how they underpin teaching techniques. Trainees interested in developing a curriculum of self-learning may be interested in " 5 Microskills for Clinical Teaching", and resources provided by the Association of American Medical Colleges (AAMC) MededPORTAL, Journal of Graduate Medical Education, and New England Journal of Medicine Resident 360 Section.

A study showed that "resident as teachers" curricula (residency integrated programs focusing on teaching) significantly improve teaching abilities, reinforce resident knowledge, and bolster postresidency placement. ${ }^{4,7}$ Accordingly, neurology training programs (e.g., UCLA, Yale) are beginning to offer longitudinal clinical-educator tracks (combining didactic series, education electives, leadership of small groups, bedside teaching, and mentored scholarly projects) within the residency. Ideally those developing educational tracks will reflect the AAMC's findings that relationship-based, noncognitive skills are a core feature of effective teaching, ${ }^{8}$ and include enhancement of a resident's "softer" skills, including leadership by example, teacher-student communication, and providing feedback, not just theoretical knowledge.

Opportunities for application of resident teaching skills are varied, including serving as teaching assistants for anatomical dissection, facilitating practicums, and providing a link between basic science and clinical application, bringing preclerkship material to life. Residents may serve as leaders of small group sessions in both preclerkship and clerkship level courses. Utilization of simulation training in neurology allows residents to serve as proctors in structured settings. Our program recruits and prepares neurology residents to engage in these opportunities in the preclerkship and clerkship level curriculum while encouraging them to engage medical students as active learners. Helping students to explain their thought process and apply their knowledge is critical, and by flipping classrooms, replacing lectures with small group and team didactics, and adding clinical simulations, training programs can enrich residents with educational exposures, allowing them to experiment and innovate in medical education. ${ }^{9}$ In addition, engaging residents to ask practical research questions about assessments, simulations, and the effect of quality improvement on clinical competency will allow them to take advantage of formal research grants funding innovative medical education projects provided by the American Academy of Neurology (AAN) Education Research Grant, AAMC, and National Board of Medical Examiners (table).

\section{Postgraduate training opportunities}

Most neurology residents enter fellowships to develop specialized skills in both application and research within a field of interest. It seems logical that similar subspecialty training would be created for future neurologic educators, and indeed, other fields have created multiple such programs. Emergency medicine leads creation of postgraduate education opportunities with 30 nonmatch fellowships. These programs vary, but typically are 1-2 years, split clinical attending duties with dedicated didactics (curriculum design, research methods), and eventually result in journal publication, grant application, or master's degree attainment.

Within neurology, medical education fellowship opportunities remain limited. A number of articles lament the difficulty of using T-32 or R25 grants in fellowship toward a clinician educator path. ${ }^{7}$ A review of Google (search terms: "neurology medical education fellowship," "neurology education fellowship"), the AAN fellowship directory, ACGME, and United Council for Neurologic Subspecialties databases showed only 1 neurology-specific education fellowship. The AAN Institute Medical Educator fellowship ${ }^{10}$ is a research-based, stipend fellowship for AAN members who have completed neurology/child neurology or neurodevelopmental disabilities residencies or fellowship in the last 5 years. A $\$ 65,000$ stipend is provided to pursue "medically oriented education research." The fellowship's focus is on research to develop behavioral and psychosocial interventions in "teaching, learning and health care practice," with an overarching goal of improving patient and family outcomes.

Do formalized fellowships create better medical teachers? There are little outcome data to provide an answer. Preliminary studies show these tracks are feasible, and graduates think positively of the programs. ${ }^{11}$ These fellowships have worth, even in early days, because they codify medical education as a scholarly career, worthy of aspiration. It is intuitively appealing that these programs will make a trainee a better teacher, and they create the expectation that medical education is an active and multifaceted career option.

In the interim, integrating medical teaching skills into existing fellowships is appealing. Possibilities in fellowship include fellows partnering with attendings in ward teaching, 
Table Abbreviated list of medical education-specific research grants

\begin{tabular}{|c|c|c|}
\hline Grant name & Website & Details \\
\hline $\begin{array}{l}\text { American Academy of } \\
\text { Neurology Education } \\
\text { Research Grant }\end{array}$ & $\begin{array}{l}\text { tools.aan.com/science/awards/?fuseaction } \\
=\text { home.info\&id = } 48\end{array}$ & $\begin{array}{l}\text { Provides support for qualitative or quantitative study of hypothesis-driven } \\
\text { observation or interventions on knowledge acquisition or training. Grants } \\
\text { include improving current American Academy of Neurology programs and } \\
\text { the study of trainee educational programs. Trainees are not eligible. }\end{array}$ \\
\hline $\begin{array}{l}\text { Stemmler Medical } \\
\text { Education Research Fund }\end{array}$ & nbme.org/research/stemmler.html & $\begin{array}{l}\text { Supports research and development of innovation in the evaluation of } \\
\text { preparing and practicing medicine. Broad topics of interest include theory, } \\
\text { knowledge, and practice assessment in medical education. Collaboration } \\
\text { is encouraged. }\end{array}$ \\
\hline $\begin{array}{l}\text { AAMC GEA National Grant } \\
\text { Award }\end{array}$ & $\begin{array}{l}\text { aamc.org/members/gea/gea_sections/ } \\
\text { mesre/ }\end{array}$ & $\begin{array}{l}\text { To encourage and support research addressing important problems in } \\
\text { medical education. Areas include faculty development, learning } \\
\text { environment, and interprofessional. Applicants must be at a GEA-affiliated } \\
\text { institution. Collaboration among other regional GEA sections is } \\
\text { encouraged. }\end{array}$ \\
\hline \multirow[t]{4}{*}{ AAMC GEA } & $\begin{array}{l}\text { Central GEA: aamc.org/members/gea/ } \\
\text { regions/cgea/357376/ } \\
\text { cgeagrantawardrecipients.html }\end{array}$ & $\begin{array}{l}\text { Regional GEA sections providing funding for medical education research } \\
\text { scholarship and evaluation. }\end{array}$ \\
\hline & $\begin{array}{l}\text { Southern GEA: aamc.org/members/gea/ } \\
\text { regions/sgea/awards/66884/sgea_ } \\
\text { research.html }\end{array}$ & \\
\hline & $\begin{array}{l}\text { Northeast GEA: aamc.org/members/gea/ } \\
\text { regions/negea/ }\end{array}$ & \\
\hline & $\begin{array}{l}\text { Western GEA: aamc.org/members/gea/ } \\
\text { regions/wgea/ }\end{array}$ & \\
\hline
\end{tabular}

Abbreviations: AAMC = Association of American Medical Colleges; GEA = Group on Education Affairs.

protecting fellow time to work with resident level trainees, and incentivizing specialty-specific education research.

Finally, educationally geared faculty development programs are provided by some academic centers, and fellows or attendings can pursue a master's degree or $\mathrm{PhD}$ in medical education, clinical education, or education. This is a formalized, but intensive route, and it is unclear to what degree it is in addition rewarded.

\section{Clinician educator and practice models post-training}

Breaking from traditional emphasis on research alone, academic centers are increasingly hiring clinician educators. A number of reasons are cited for this change, including competitive research funding, increased numbers of trainees, and increased clinical care needs. ${ }^{7}$

The acceptance of the clinician-educator is seen in clinical professorship tracks. Promotion criteria on these tracks vary, but generally require longitudinal dedication to teaching activities and mentorship, with demonstration of quality and quantity of teaching exceeding that of peers. Certain institutions have begun to grapple with the challenges of financially incentivizing teaching by developing an educational relative value unit (RVU) system. The RVU system is a scale to adjust payment by intensity of clinical resources used for providerpatient interactions. Educational RVUs would analogously assign monetary value to teacher-learner interactions. ${ }^{12}$ This incentivization on a national level is imperative to elevating the role of clinician-educators. ${ }^{2}$ Financially supported educational leadership positions include the preclerkship course director, clerkship director, residency program director, and roles within Medical Education administration. Uncompensated but meaningful opportunities to affect neurology education include service on standard setting subsections at national meetings and developing test material for licensure with the National Board of Medical Examiners, American Board of Psychiatry and Neurology, and a variety of subspecialty entities.

Medical education is a rapidly growing field in neurology, but is still young. We describe the current landscape of opportunities in medical education, and at present, due to few formal training opportunities in neurologic medical education, place the onus on self-motivated residents to explore their interest in teaching, and to enhance their abilities as educators. Opportunities to develop formal neurology education curricula and to support dedicated postresidency fellowships abound. Neurology should keep pace with other fields in advancing current and future clinician-educators.

\section{Study funding}

No targeted funding reported.

\section{Disclosure}

The authors report no disclosures relevant to the manuscript. Go to Neurology.org/N for full disclosures. 
Appendix Authors

\begin{tabular}{|c|c|c|c|}
\hline Name & Location & Role & Contribution \\
\hline $\begin{array}{l}\text { Patrick } \\
\text { M. Chen, } \\
\text { MD }\end{array}$ & $\begin{array}{l}\text { University of } \\
\text { California, San } \\
\text { Diego }\end{array}$ & Author & $\begin{array}{l}\text { Study concept and design, } \\
\text { acquisition of data, analysis and } \\
\text { interpretation, critical revision of } \\
\text { the manuscript for important } \\
\text { intellectual content, read and } \\
\text { approved the final manuscript }\end{array}$ \\
\hline $\begin{array}{l}\text { Sean J. } \\
\text { Evans, } \\
\text { MD }\end{array}$ & $\begin{array}{l}\text { University of } \\
\text { California, San } \\
\text { Diego }\end{array}$ & Author & $\begin{array}{l}\text { Analysis and interpretation, } \\
\text { critical revision of the } \\
\text { manuscript for important } \\
\text { intellectual content, study } \\
\text { supervision, read and approved } \\
\text { the final manuscript }\end{array}$ \\
\hline
\end{tabular}

\section{References}

1. McCarron MO, Stevenson M, Loftus AM, McKeown P. Neurophobia among general practice trainees: the evidence, perceived causes and solutions. Clin Neurol Neurosurg 2014;122:124-128.

2. Lin DJ, Cudkowicz ME, Cho TA. Opinion and Special Articles: challenges and opportunities in defining career identity in academic neurology. Neurology 2018;91:670-672.
3. Dyrbye LN, Burke SE, Hardeman RR, et al. Association of clinical specialty with symptoms of burnout and career choice regret among US resident physicians. JAMA 2018;320:1114-1130.

4. Smith CC, McCormick I, Huang GC. The clinician-educator track: training interna medicine residents as clinician-educators. Acad Med 2014;89:888-891.

5. The Accreditation Council for Graduate Medical Education. The neurology milestone project [online]. Available at: acgme.org/Specialties/Milestones/pfcatid/37/ Neurology. Accessed March 19, 2019.

6. Neher JO, Gordon KC, Meyer B, Stevens N. A five-step "microskills" model of clinical teaching. J Am Board Fam Pract 1992;5:419-424.

7. Adamson R, Goodman RB, Kritek P, Luks AM, Tonelli MR, Benditt J. Training the teachers: the clinician-educator track of the University of Washington Pulmonary and Critical Care Medicine Fellowship Program. Ann Am Thorac Soc 2015;12: 480-485.

8. Sutkin G, Wagner E, Harris I, Schiffer R. What makes a good clinical teacher in medicine? A review of the literature. Acad Med 2008;83:452-466.

9. Schaefer SM, Dominguez M, Moeller JJ. The future of the lecture in neurology education. Semin Neurol 2018;38:418-427.

10. American Academy of Neurology. Medical education research training fellowship [online]. Available at: tools.aan.com/science/awards/?fuseaction=home.info\&id=89. Accessed March 19, 2019.

11. Ahn J, Martin SK, Farnan JM, Fromme HB. The graduate medical education scholars track: developing residents as clinician-educators during clinical training via a longitudinal, multimodal, and multidisciplinary track. Acad Med 2018;93: 214-219.

12. Nutter DO, Bond JS, Coller BS, et al. Measuring faculty effort and contributions in medical education. Acad Med 2000;75:199-207.

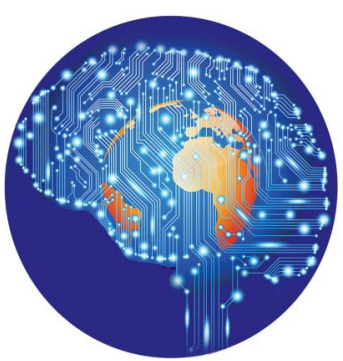

\section{Practice Current: An interactive exchange on controversial topics}

Share your own best practices.

Read commentary with expert opinion.

Explore results on an interactive world map.

\section{Disputes \& Debates: Rapid online correspondence}

The editors encourage comments on recent articles through Disputes \& Debates:

Access an article at Neurology.org/N and click on "COMMENT" beneath the article header. Responses will be posted within 3 business days.

Before submitting a comment to Disputes \& Debates, remember the following:

- Disputes \& Debates is restricted to comments about studies published in Neurology within the last eight weeks

- Read previously posted comments; redundant comments will not be posted

- Your submission must be 200 words or less and have a maximum of five references; reference one must be the article on which you are commenting

- You can include a maximum of five authors (including yourself) 


\title{
Neurology
}

\author{
Emerging Subspecialties in Neurology: Medical education \\ Patrick M. Chen and Sean J. Evans \\ Neurology 2019;93;273-276 \\ DOI 10.1212/WNL.0000000000007904
}

This information is current as of August 5, 2019

\begin{tabular}{|c|c|}
\hline $\begin{array}{l}\text { Updated Information \& } \\
\text { Services }\end{array}$ & $\begin{array}{l}\text { including high resolution figures, can be found at: } \\
\text { http://n.neurology.org/content/93/6/273.full }\end{array}$ \\
\hline References & $\begin{array}{l}\text { This article cites } 10 \text { articles, } 2 \text { of which you can access for free at: } \\
\text { http://n.neurology.org/content/93/6/273.full\#ref-list-1 }\end{array}$ \\
\hline Citations & $\begin{array}{l}\text { This article has been cited by } 1 \text { HighWire-hosted articles: } \\
\text { http://n.neurology.org/content/93/6/273.full\#\#otherarticles }\end{array}$ \\
\hline Subspecialty Collections & $\begin{array}{l}\text { This article, along with others on similar topics, appears in the } \\
\text { following collection(s): } \\
\text { All Education } \\
\text { http://n.neurology.org/cgi/collection/all_education } \\
\text { Methods of education } \\
\text { http://n.neurology.org/cgi/collection/methods_of_education }\end{array}$ \\
\hline Permissions \& Licensing & $\begin{array}{l}\text { Information about reproducing this article in parts (figures,tables) or in } \\
\text { its entirety can be found online at: } \\
\text { http://www.neurology.org/about/about_the_journal\#permissions }\end{array}$ \\
\hline Reprints & $\begin{array}{l}\text { Information about ordering reprints can be found online: } \\
\text { http://n.neurology.org/subscribers/advertise }\end{array}$ \\
\hline
\end{tabular}

Neurology ${ }^{\circledR}$ is the official journal of the American Academy of Neurology. Published continuously since 1951, it is now a weekly with 48 issues per year. Copyright () 2019 American Academy of Neurology. All rights reserved. Print ISSN: 0028-3878. Online ISSN: 1526-632X.

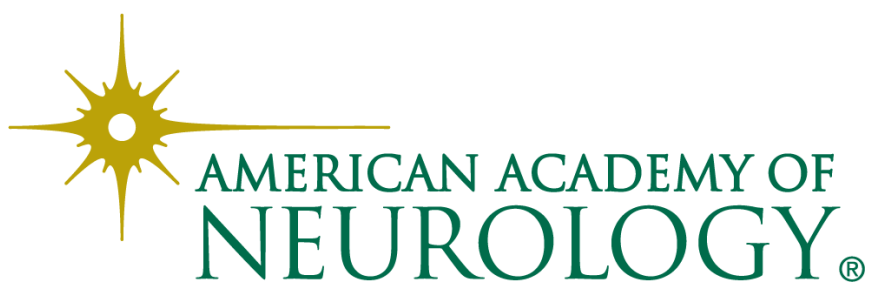

